\title{
Recent advances in managing/understanding the metabolic
}

\section{syndrome [version 1; peer review: 3 approved]}

\author{
Carlos A. Aguilar-Salinas (D1-3, Tannia Viveros-Ruiz1,4 \\ 1Unidad de Investigación en Enfermedades Metabólicas, Instituto Nacional de Ciencias Médicas y Nutrición Salvador Zubirán, \\ Mexico City, 14008, Mexico \\ ${ }^{2}$ Departamento de Endocrinología y Metabolismo, Instituto Nacional de Ciencias Médicas y Nutrición Salvador Zubirán, Mexico City, \\ 14008 , Mexico \\ ${ }^{3}$ Escuela de Medicina y Ciencias de la Salud, Tecnologico de Monterrey, Monterrey, Nuevo Leon, 64710, Mexico \\ ${ }^{4}$ Doctorado de Epidemiología Clínica, Universidad Nacional Autónoma de México, Mexico City, 04510, Mexico
}

V1 First published: 03 Apr 2019, 8(F1000 Faculty Rev):370

https://doi.org/10.12688/f1000research.17122.1

Latest published: 03 Apr 2019, 8(F1000 Faculty Rev):370

https://doi.org/10.12688/f1000research.17122.1

\section{Abstract}

The metabolic syndrome (MetS) concept gathers in a single entity a set of metabolic abnormalities that have in common a close relationship with ectopic deposit of lipids, insulin resistance, and chronic low-grade inflammation. It is a valuable teaching tool to help health professionals to understand and integrate the consequences of lipotoxicity and the adverse metabolic consequences of insulin resistance. Also, it is useful to identify subjects with a high risk for having incident type 2 diabetes. Systems biology studies have gained a prominent role in understanding the interaction between adipose tissue dysfunction, insulin action, and the MetS traits and comorbidities (that is, non-alcoholic steatohepatitis, or NASH). This approach may allow the identification of new therapeutic targets (that is, de novo lipogenesis inhibitors for NASH). Treatment targets on MetS are the adoption of a healthy lifestyle, weight loss, and the control of the co-morbidities (hyperglycemia, dyslipidemia, arterial hypertension, among others). The long-term goals are the prevention of type 2 diabetes, cardiovascular events, and other MetS-related outcomes. In the last few decades, new drugs derived from the identification of innovative treatment targets have come on the market. These drugs have positive effects on more than one MetS component (that is, hyperglycemia and weight control). New potential treatment targets are under study.

\section{Keywords}

Metabolic syndrome, lipotoxicity, obesity, type 2 diabetes, hypertriglyceridemia

\section{Open Peer Review}

Approval Status

1

2

3

version 1

03 Apr 2019

Faculty Reviews are review articles written by the prestigious Members of Faculty Opinions. The articles are commissioned and peer reviewed before publication to ensure that the final, published version is comprehensive and accessible. The reviewers who approved the final version are listed with their names and affiliations.

1. Christopher Byrne, University of Southampton, Southampton, UK

2. Neil Stone, Northwestern University Feinberg School of Medicine, Chicago, USA

3. Jorge Calles-Escandon, Case Western Reserve University School of Medicine, Cleveland, USA

Any comments on the article can be found at the end of the article. 
Corresponding author: Carlos A. Aguilar-Salinas (caguilarsalinas@yahoo.com)

Author roles: Aguilar-Salinas CA: Conceptualization, Writing - Review \& Editing; Viveros-Ruiz T: Writing - Original Draft Preparation Competing interests: No competing interests were disclosed.

Grant information: The author(s) declared that no grants were involved in supporting this work.

Copyright: $\odot 2019$ Aguilar-Salinas CA and Viveros-Ruiz T. This is an open access article distributed under the terms of the Creative Commons Attribution License, which permits unrestricted use, distribution, and reproduction in any medium, provided the original work is properly cited.

How to cite this article: Aguilar-Salinas CA and Viveros-Ruiz T. Recent advances in managing/understanding the metabolic syndrome [version 1; peer review: 3 approved] F1000Research 2019, 8(F1000 Faculty Rev):370

https://doi.org/10.12688/f1000research.17122.1

First published: 03 Apr 2019, 8(F1000 Faculty Rev):370 https://doi.org/10.12688/f1000research.17122.1 


\section{Introduction}

The metabolic syndrome (MetS) concept gathers in a single entity a set of metabolic abnormalities that have in common a close relationship with ectopic deposit of lipids, insulin resistance, and chronic low-grade inflammation. In many cases, a chronic exposure to a positive caloric balance is the driving force for the appearance and progression of this condition. The main traits included in MetS diagnosis are arterial hypertension, central adiposity, hyperglycemia, and atherogenic dyslipidemia ${ }^{1}$. Several other conditions are related to similar metabolic derangements (that is, liver steatosis, polycystic ovary syndrome, and hyperuricemia) but are not part of the MetS diagnostic criteria. The main long-term complications of MetS are type 2 diabetes $^{2}$, atherogenesis ${ }^{3}$, and cognitive impairment ${ }^{4}$.

Controversy has surrounded the definition of MetS $\mathrm{S}^{5,6}$. Several definitions (composed of dissimilar traits and thresholds) were proposed for its identification over the past 20 years. This clinical construct has been used as a diagnosis, a risk factor, or even an outcome. Contrasting results have been informed when the added value of MetS is compared against the information derived from each one of its individual components for the prediction, prevention, and treatment of its long-term complications. Also, it has been considered a valuable teaching tool to help health professionals to understand and integrate the consequences of a chronic positive caloric balance and the adverse metabolic consequences of excess body weight ${ }^{7}$.

In this short review, we discuss recent advances in the diagnosis and clinical use of MetS. Also, new findings in its pathophysiology and treatment are highlighted in the final section of the article.

\section{Metabolic syndrome: definition}

MetS definitions are composed of one or more clinical variables or biomarkers of the presence of the main traits (Table 1) included in the MetS concept (central adiposity, hypertension, high triglycerides, low high-density lipoprotein cholesterol, and hyperglycemia $)^{8-13}$. The selection of the variables and its thresholds has been a complex task because the main MetS traits could be assessed by several indicators that provide complementary information (for example, fasting plasma glucose, HbAlc, or even the 2-hour glucose concentration after an oral glucose load for the "hyperglycemia" trait). In addition, authors have applied diverging conceptual models to build their diagnostic frame. For example, the International Diabetes Federation and the National Cholesterol Education Program (NCEP) definitions are focused on central obesity; in contrast, the World Health Organization definition is focused on insulin resistance. As a result, these tools identify heterogeneous populations as having the same condition. The existence of several MetS definitions created inconsistent results and confusion. However, the practicality of the NCEP criteria ${ }^{9}$ (or its harmonized version ${ }^{8}$ ) has made this diagnostic tool the most accepted diagnostic criterion. Its use has been included in some obesity and cardiovascular risk guidelines ${ }^{14}$. However, it is questionable that the inclusion of MetS in the clinical assessment or the prognostic evaluation of at-risk cases for having non-communicable diseases provides more information than that obtained by the evaluation of each one of the MetS traits. As a consequence, several groups have proposed alternative approaches intended to be used in research. To avoid arbitrary decisions in the selection of the thresholds to define abnormal values of the MetS traits, our group proposed a score based on the population-based distribution of each one of the MetS components ${ }^{15}$. One point was given per decile for every component. The total number of points accumulated was used to classify subjects. Individuals in the upper quartile of the point scale ( $\geq 39$ points) had an odds ratio to have incident diabetes significantly greater than that found with the NCEP criteria (12.71 versus 11.14). The advantage of this approach is the detection of subjects at the extreme of the range of diabetes risk and the ability to estimate the risk as a continuum. A similar approach was applied to develop the MetS-Z score, which is based on the weighted contribution of each component on a sex- and race-specific basis derived from the US National Health and Nutrition Examination Survey. This approach is capable of predicting incident type 2 diabetes and cardiovascular events ${ }^{16}$. In a recent report, MetS-Z score was applied to assess the response to a healthy lifestyle program in the Diabetes Prevention Program. The 1- to 5-year risk of incident diabetes was strongly associated with 1-year changes in MetS-Z score and waist circumference (hazard ratios for a 1 -standard deviation increase $=1.80$ ), whereas the risk of cardiovascular disease was associated with a 1-year change in MetS-Z score, glucose, and systolic blood pressure ${ }^{17}$. These observations suggest that the MetS definition is still a work in progress. The use of continuous scores may be an option to improve the identification of at-risk individuals and to assess their response to therapy. Some of the continuous definitions are highlighted in Table $2^{17-21}$. However, its translation into clinical practice will require the demonstration of a clear advantage of its use over current conventional practice. As a consequence, MetS cannot be considered a treatment goal or an outcome ${ }^{22}$.

Nearly $30 \%$ of obese individuals are free of metabolic co-morbidities ${ }^{23}$. This phenotype has been called "metabolically healthy obesity" (MHO). The MetS definitions have been adapted to identify this condition. However, more than five versions derived from the NCEP definition have been proposed. We should learn from the past ${ }^{24}$. The definition of a clinical construct should be based on evidence and a conceptual model. The MHO is a biological model with limited clinical implications.

\section{Pathogenesis of metabolic syndrome}

The underlying mechanism by which the MetS components share aspects of their pathophysiology is a matter of intense research. The capacity of the adipose tissue to expand and store energy substrates plays a critical role in its pathophysiology. However, other metabolic pathways should be involved since the same metabolic abnormalities seen in MetS could happen in lean individuals ${ }^{25}$. Systems biology approaches and omics-based research have been critical to develop new holistic models ${ }^{26}$. This is the case for the recently published systems biology studies carried out in patients with non-alcoholic steatohepatitis ${ }^{27}$. Based on this approach, the involvement of several metabolic 


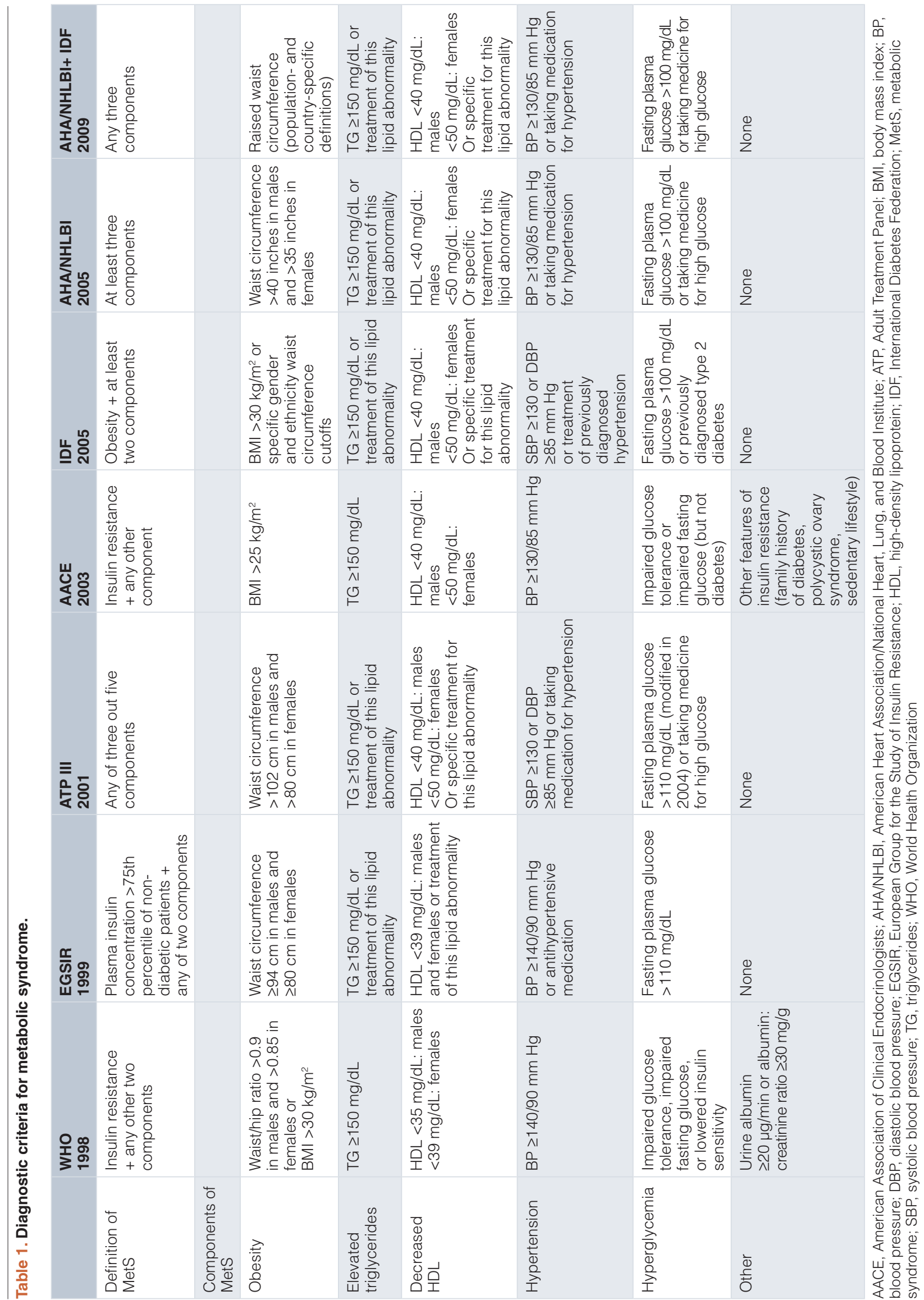


Table 2. Some continuous scores for the diagnosis of metabolic syndrome.

\begin{tabular}{|l|l|l|}
\hline Authors & Statistical approach & Clinical use \\
\hline Aguilar-Salinas et al. & $\begin{array}{l}\text { Population-based distribution of the main } \\
\text { traits of metabolic syndrome }\end{array}$ & Prediction of incident diabetes \\
\hline DeBoer et al. & Metabolic syndrome-Z score & $\begin{array}{l}\text { Prediction of incident diabetes and } \\
\text { cardiovascular events } \\
\text { Assessment of response to a diabetes } \\
\text { prevention program }\end{array}$ \\
\hline Magnussen et al. & $\begin{array}{l}\text { Principal component analyses } \\
\text { Sum of standardized Z scores } \\
\text { Sum of standardized residuals }\end{array}$ & Prediction of cardiometabolic outcomes \\
\hline Wijndaele et al. & Principal component analyses & 18 \\
\hline Janghorbani and Amini & Age and gender Z scores & $\begin{array}{l}\text { Assessment of the severity of the metabolic } \\
\text { abnormalities }\end{array}$ \\
\hline Kang et al. & $\begin{array}{l}\text { Sum of points derived from a Cox regression } \\
\text { model }\end{array}$ & \begin{tabular}{l} 
Prediction of cardiovascular outcomes \\
\hline
\end{tabular} \\
\hline
\end{tabular}

pathways (de novo lipogenesis, beta oxidation, pyruvate utilization, and serine and glutathione synthesis) was recognized. Some of them are activated to handle the excessive flux of energy precursors found in MetS and to prevent the accumulation of oxygen radicals. Furthermore, the critical role of pyruvate kinase liver red cell $(P K L R)$ as a determinant of triglyceride accumulation in the liver was identified ${ }^{28}$. In summary, lipotoxicity, low-grade chronic inflammation, and insulin resistance are the prevailing complementary mechanisms that the majority of groups consider the core of MetS pathogenesis. Its description goes beyond the scope of this review. Interested readers will find the description of the state of the art of this field in outstanding reviews included in the References section ${ }^{29-33}$.

In the near future, the study of the contribution of new approaches (that is, metagenomics, impact of environmental factors on the epigenome, and expansion or differentiation of adipose tissue, among others) may become novel evidence to improve innovative targets for prevention or treatment ${ }^{34-37}$.

\section{Management of metabolic syndrome}

Treatment targets on MetS are the adoption of a healthy lifestyle, weight loss, and the control of co-morbidities (hyperglycemia, dyslipidemia, and arterial hypertension, among others $)^{38}$ (Figure 1). The long-term goals are the prevention of type 2 diabetes, cardiovascular events, and other MetS-related outcomes (that is, dementia and chronic liver disease).

The adoption of a healthy lifestyle is the cornerstone of MetS treatment. Diet, physical activity, sleep, emotion control, peer support, and avoidance of tobacco, alcohol, and other drugs/ medications that alter satiety or body weight are key targets of any healthy lifestyle program. Each one requires a systematic assessment and a patient-centered intervention plan. Knowledge, beliefs, fears, barriers to achieve adherence to therapy, and motivation to change should be evaluated for each target ${ }^{39}$. Algorithms or intervention plans based on patient profiles are conventional strategies to intervene. In many health systems, innovative approaches (that is, app-based support systems and web-based interventions) have reinforced the intervention plans. However, many challenges remain unsolved. In a large proportion of cases, the effect of the intervention is short-lived. The intervention does not alter major environmental and sociodemographic factors that determine health-related conduct; as a result, unhealthy behaviors persist.

The MetS concept could be used as a teaching tool in healthy lifestyle programs. This approach was applied in the The Reversal Intervention for Metabolic Syndrome (TRIMS) study ${ }^{40}$. During a 55-minute session, participants discussed with health professionals the contributing factors for having MetS and the health risks that could be avoided. However, the impact of the session was not analyzed separately from the overall intervention. The same limitation is found in meta-analyses that have measured the effect of lifestyle programs on the prevention of type 2 diabetes and other MetS long-term risks ${ }^{41}$.

A prime objective is weight loss. Even a small weight loss (3\% or more) results in an improvement in several MetS components. The most likely explanation for that is the high turnover rate of the intra-abdominal fat depots; as a result, a slight weight loss reduces the liver exposure to fatty acids and other proinflammatory mediators. A sustained weight loss greater than $10 \%$ could be enough to reverse glucose intolerance, arterial hypertension, and several of the lipoprotein abnormalities. The best source of evidence of the prominent role of weight loss in MetS treatment is bariatric surgery, in which a 30 to $40 \%$ weight loss is capable of reversing the majority of the MetS abnormalities $^{42}$. This action is not exclusive to bariatric surgery ${ }^{43}$. In addition, complementary mechanisms of bariatric surgery beyond weight loss (that is, farnesoid $\mathrm{X}$ receptor [FXR] activation, changes in incretin secretion, or modification of microbiota) have been postulated ${ }^{44}$. Despite the above, weight loss is an unmet need for many MetS cases. Few cases attain ideal body weight or maintain weight loss over time. 


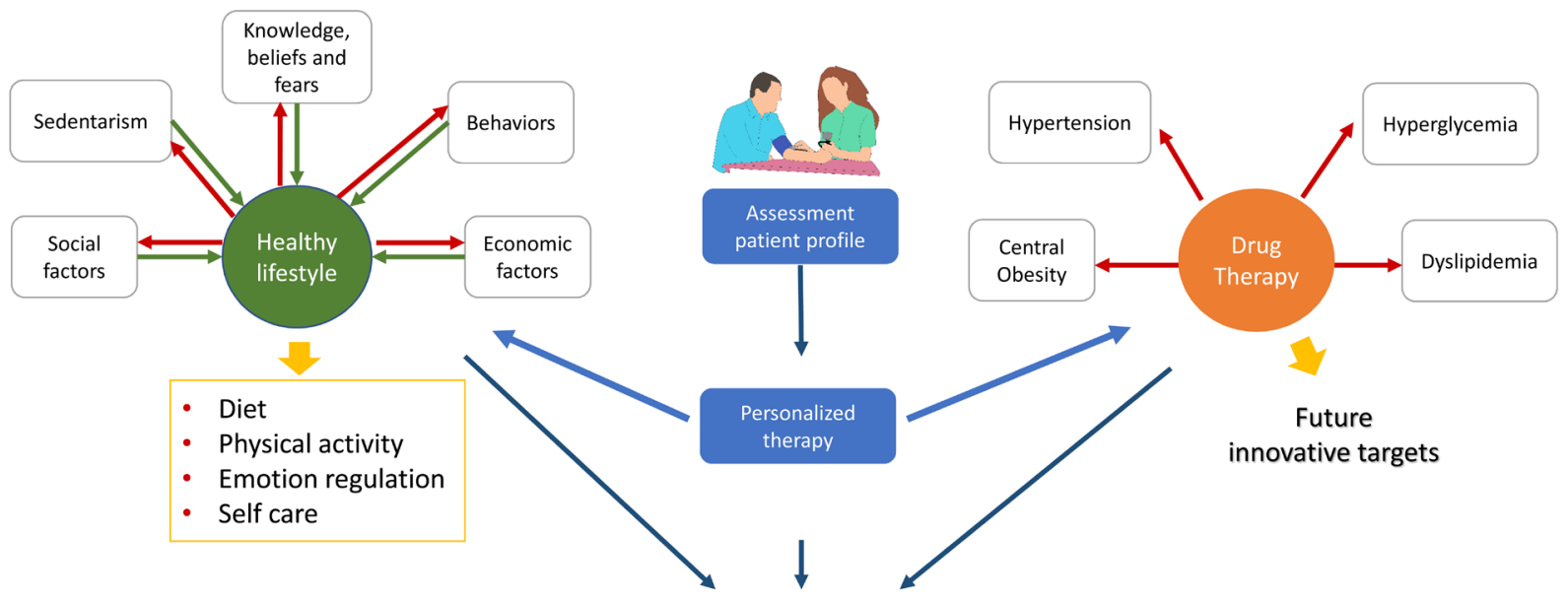

Prevention or control of:

- Type 2 diabetes

- Cardiovascular events

- Dementia

- Some cancers

Figure 1. Treatment of metabolic syndrome. A personalized approach should be applied in the adoption of a healthy lifestyle and in the prescription of drug therapy. Adherence is a major challenge that could be overcome by identifying the patient profile, estimating the empowerment and addressing the main or most common barriers to include therapy in the daily routines.

The third treatment target is the control of co-morbidities. Effective drug therapies are available for treating hyperglycemia, arterial hypertension, and dyslipidemia. As a result, the accomplishment of this target is the most likely approach to be implemented in primary care centers to prevent MetS-related outcomes. Metformin, statins, angiotensin-converting enzyme (ACE) inhibitors, and angiotensin receptor blockers are among the most frequent drugs used to treat co-morbidities. In the last few decades, new drugs derived from the identification of innovative treatment targets have come on the market. This is the case with the glucagon-like-peptide 1 (GLP-1) agonists, sodium-glucose co-transporter 2 (SGLT2) inhibitors, and dipeptidyl peptidase 4 (DPP4) inhibitors ${ }^{44}$. These drugs have positive effects on more than one MetS component (that is, hyperglycemia and weight control). Preliminary data suggest that GLP-1 agonists and SGLT2 inhibitors may reduce cardiovascular or renal outcomes ${ }^{45,46}$. Long-term studies are under development to demonstrate the effectiveness of such interventions. Cost-effectiveness analyses are needed to integrate these therapies in the majority of health systems. New potential treatment targets are under study. This is the case with FXR agonists ${ }^{47}$, new peroxisome proliferatoractivated receptor (PPAR)-gamma or PPAR-alpha modulators ${ }^{48,49}$, GIP/GLP1 dual agonists $^{50}$, dual SGLT1/SGLT2 inhibitors ${ }^{51}$,
G protein-coupled receptor (GPCR/GPR) agonists ${ }^{52}$, apical sodium-dependent bile acid transporter (ASBT) inhibitors ${ }^{53}$, chemokine receptor 2 and 5 antagonists, fibroblast growth factor 19 agonists $^{54}$, and modulators of microbiota or their products among many others MetS treatment is an area under intense investigation. However, owing to long-term safety issues, the introduction of new agents is not as fast as needed.

\section{Conclusions}

MetS is a topic in which many disciplines are interested. Besides which definition is used, the MetS concept is a valuable tool in medical education. It provides an overview of the complex mechanisms by which chronic exposure to a positive caloric balance or lipotoxicity (or both) causes long-term complications. Implementing cost-effective therapies and developing new therapeutic strategies for MetS should be considered high-priority areas.

\section{Grant information}

The author(s) declared that no grants were involved in supporting this work.
1. O'Neill S, O'Driscoll L: Metabolic syndrome: a closer look at the growing epidemic and its associated pathologies. Obes Rev. 2015; 16(1): 1-12. PubMed Abstract | Publisher Full Text

2. $\mathrm{F}$ Salehinia $\mathrm{F}$, Abdi $\mathrm{H}$, Hadaegh $\mathrm{F}$, et al:: Abdominal obesity phenotypes and incident diabetes over 12 years of follow-up: The Tehran Lipid and glucose study. Diabetes Res Clin Pract. 2018; 144: 17-24. PubMed Abstract | Publisher Full Text | F1000 Recommendation

3. F Riahi SM, Moamer S, Namdari M, et al:: Patterns of clustering of the metabolic syndrome components and its association with coronary heart disease in the Multi-Ethnic Study of Atherosclerosis (MESA): A latent class 
analysis. Int J Cardiol. 2018; 271: 13-8.

PubMed Abstract | Publisher Full Text | F1000 Recommendation

4. $\quad F$ Ng TP, Feng L, Nyunt MS, et al:: Metabolic Syndrome and the Risk of Mild Cognitive Impairment and Progression to Dementia: Follow-up of the Singapore Longitudinal Ageing Study Cohort. JAMA Neurol. 2016; 73(4): 456-63. PubMed Abstract | Publisher Full Text | F1000 Recommendation

5. Kassi E, Pervanidou P, Kaltsas G, et al.: Metabolic syndrome: definitions and controversies. BMC Med. 2011; 9: 48. PubMed Abstract | Publisher Full Text | Free Full Text

6. F Dommermuth R, Ewing K: Metabolic Syndrome: Systems Thinking in Heart Disease. Prim Care. 2018; 45(1): 109-29.

PubMed Abstract | Publisher Full Text | F1000 Recommendation

7. Aguilar CA, Rojas R, Gómez-Pérez FJ, et al:: The Metabolic Syndrome: A Concept Hard to Define. Arch Med Res. 2005; 36(3): 223-31. PubMed Abstract | Publisher Full Text

8. Alberti KG, Zimmet $P$, Shaw J: Metabolic syndrome--a new world-wide definition. A Consensus Statement from the International Diabetes Federation. Diabet Med. 2006; 23(5): 469-80.

PubMed Abstract | Publisher Full Text

9. Alberti KG, Zimmet PZ: Definition, diagnosis and classification of diabetes mellitus and its complications. Part 1: Diagnosis and classification of diabetes mellitus provisional report of a WHO Consultation. Diabet Med. 1998; 15(7): 539-53.

PubMed Abstract | Publisher Full Text

10. Balkau B, Charles MA: Comment on the provisional report from the WHO consultation. European Group for the Study of Insulin Resistance (EGIR). Diabet Med. 1999; 16(5): 442-3.

PubMed Abstract

11. Expert Panel on Detection, Evaluation, and Treatment of High Blood Cholesterol in Adults: Executive Summary of the Third Report of the National Cholestero Education Program (NCEP) Expert Panel on Detection, Evaluation, and Treatment of High Blood Cholesterol in Adults (Adult Treatment Panel III) JAMA. 2001; 285(19): 2486-97.

PubMed Abstract | Publisher Full Text

12. Einhorn D, Reaven GM, Cobin RH, et al.: American College of Endocrinology position statement on the insulin resistance syndrome. Endocr Pract. 2003; 9(3): 237-52.

PubMed Abstract | Publisher Full Text

13. Grundy SM, Cleeman JI, Daniels SR, et al:: Diagnosis and management of the metabolic syndrome: An American Heart Association/National Heart, Lung, and Blood Institute Scientific Statement. Circulation. 2005; 112(17): 2735-52. PubMed Abstract | Publisher Full Text

14. F Ryan DH, Kahan S: Guideline Recommendations for Obesity Management Med Clin North Am. 2018; 102(1): 49-63.

PubMed Abstract | Publisher Full Text | F1000 Recommendation

15. Aguilar-Salinas CA, Rojas R, Gonzalez-Villalpando C, et al:: Design and validation of a population-based definition of the metabolic syndrome. Diabetes Care. 2006; 29(11): 2420-6.

PubMed Abstract | Publisher Full Tex

16. F Gurka MJ, Filipp SL, Pearson TA, et al:: Assessing Baseline and Tempora Changes in Cardiometabolic Risk Using Metabolic Syndrome Severity and Common Risk Scores. J Am Heart Assoc. 2018; 7(16): e009754

PubMed Abstract | Publisher Full Text | Free Full Text | F1000 Recommendation

17. F DeBoer MD, Filipp SL, Gurka MJ: Use of a Metabolic Syndrome Severity $Z$ Score to Track Risk During Treatment of Prediabetes: An Analysis of the Diabetes Prevention Program. Diabetes Care. 2018; 41(11): 2421-30. PubMed Abstract | Publisher Full Text | Free Full Text | F1000 Recommendation

18. Magnussen CG, Cheriyan S, Sabin MA, et al:: Continuous and Dichotomous Metabolic Syndrome Definitions in Youth Predict Adult Type 2 Diabetes and Carotid Artery Intima Media Thickness: The Cardiovascular Risk in Young Finns Study. J Pediatr. 2016; 171: 97-103.e1-3. PubMed Abstract | Publisher Full Tex

19. Wijndaele K, Beunen G, Duvigneaud N, et al.: A continuous metabolic syndrom risk score: utility for epidemiological analyses. Diabetes Care. 2006; 29(10): 2329

PubMed Abstract | Publisher Full Text

20. Janghorbani M, Amini M: Utility of Continuous Metabolic Syndrome Score in Assessing Risk of Type 2 Diabetes: The Isfahan Diabetes Prevention Study. Ann Nutr Metab. 2016; 68(1): 19-25. PubMed Abstract | Publisher Full Text

21. Kang GD, Guo L, Guo ZR, et al.: Continuous metabolic syndrome risk score for predicting cardiovascular disease in the Chinese population. Asia Pac J Clin Nutr. 2012; 21(1): 88-96.

PubMed Abstract

22. Colman E: Food and Drug Administration's Obesity Drug Guidance Document: a short history. Circulation. 2012; 125(17): 2156-64.

PubMed Abstract | Publisher Full Text

23. F Schulze MB: Metabolic health in normal-weight and obese individuals. Diabetologia. 2019; 62(4): 558-566.

PubMed Abstract | Publisher Full Text | F1000 Recommendation

24. Phillips CM: Metabolically healthy obesity: definitions, determinants and clinical implications. Rev Endocr Metab Disord. 2013; 14(3): 219-27. PubMed Abstract | Publisher Full Text

25. F Carobbio S, Pellegrinelli V, Vidal-Puig A: Adipose Tissue Function and Expandability as Determinants of Lipotoxicity and the Metabolic Syndrome. Adv Exp Med Biol. 2017; 960: 161-96. PubMed Abstract | Publisher Full Text | F1000 Recommendation

26. F Nielsen J: Systems Biology of Metabolism: A Driver for Developing Personalized and Precision Medicine. Cell Metab. 2017; 25(3): 572-9. PubMed Abstract | Publisher Full Text | F1000 Recommendation

27. F Lovric A, Granér M, Bjornson E, et al.: Characterization of different fat depots in NAFLD using inflammation-associated proteome, lipidome and metabolome. Sci Rep. 2018; 8(1): 14200.

PubMed Abstract | Publisher Full Text | Free Full Text | F1000 Recommendation

28. F Liu Z, Zhang C, Lee S, et al.: Pyruvate kinase L/R is a regulator of lipid metabolism and mitochondrial function. Metab Eng. 2019; 52: 263-72. PubMed Abstract | Publisher Full Text | F1000 Recommendation

29. F Crewe C, An YA, Scherer PE: The ominous triad of adipose tissue dysfunction: Inflammation, fibrosis, and impaired angiogenesis. J Clin Invest. 2017; 127(1): 74-82.

PubMed Abstract | Publisher Full Text | Free Full Text | F1000 Recommendation

30. Welty FK, Alfaddagh A, Elajami TK: Targeting inflammation in metabolic syndrome. Trans/ Res. 2016; 167(1): 257-80.

PubMed Abstract | Publisher Full Text

31. Lackey DE, Olefsky JM: Regulation of metabolism by the innate immune system. Nat Rev Endocrinol. 2016; 12(1): 15-28. PubMed Abstract | Publisher Full Text

32. F Petersen MC, Vatner DF, Shulman GI: Regulation of hepatic glucose metabolism in health and disease. Nat Rev Endocrinol. 2017; 13(10): 572-87. PubMed Abstract | Publisher Full Text | Free Full Text | F1000 Recommendation

33. Samuel VT, Shulman GI: The pathogenesis of insulin resistance: integrating signaling pathways and substrate flux. J Clin Invest. 2016; 126(1): 12-22. PubMed Abstract | Publisher Full Text | Free Full Text

34. Ussar S, Fujisaka S, Kahn CR: Interactions between host genetics and gut microbiome in diabetes and metabolic syndrome. Mol Metab. 2016; 5(9): 795-803. PubMed Abstract | Publisher Full Text | Free Full Text

35. Stone WL, Schetzina K, Stuart C: Childhood obesity: a systems medicine approach. Front Biosci (Landmark Ed). 2016; 21: 1061-75. PubMed Abstract | Publisher Full Text

36. Blüher M: Adipose tissue inflammation: a cause or consequence of obesityrelated insulin resistance? Clin Sci (Lond). 2016; 130(18): 1603-14. PubMed Abstract | Publisher Full Text

37. F Bargut TCL, Souza-Mello V, Aguila MB, et al:: Browning of white adipose tissue: lessons from experimental models. Horm Mol Biol Clin Investig. 2017; 31(18): pii: /j/hmbci.2017.31.issue-1/hmbci-2016-0051/hmbci-2016-0051.xml. PubMed Abstract | Publisher Full Text | F1000 Recommendation

38. Grundy SM: Metabolic syndrome update. Trends Cardiovasc Med. 2016; 26(4): 364-73.

PubMed Abstract | Publisher Full Text

39. F Aspry KE, Van Horn L, Carson JAS, et al.: Medical Nutrition Education, Training, and Competencies to Advance Guideline-Based Diet Counseling by Physicians: A Science Advisory From the American Heart Association. Circulation. 2018; 137(23): e821-e841. Circulation. 2018; 137(23): e821-e841.
PubMed Abstract | Publisher Full Text | F1000 Recommendation

40. Dunkley AJ, Davies MJ, Stone MA, et al:: The Reversal Intervention for Metabolic Syndrome (TRIMS) study: rationale, design, and baseline data. Trials. 2011; 12: 107.

PubMed Abstract | Publisher Full Text | Free Full Text

41. Dunkley AJ, Bodicoat DH, Greaves CJ, et al: Diabetes prevention in the real world: effectiveness of pragmatic lifestyle interventions for the prevention of type 2 diabetes and of the impact of adherence to guideline recommendations: a systematic review and meta-analysis. Diabetes Care. 2014; 37(4): 922-33. PubMed Abstract | Publisher Full Text

42. F de Toro-Martín J, Arsenault BJ, Després JP, et al:: Precision Nutrition: A Review of Personalized Nutritional Approaches for the Prevention and Management of Metabolic Syndrome. Nutrients. 2017; 9(8): pii: E913. PubMed Abstract | Publisher Full Text | Free Full Text | F1000 Recommendation

43. Madsbad S, Dirksen C, Holst JJ: Mechanisms of changes in glucose metabolism and bodyweight after bariatric surgery. Lancet Diabetes Endocrinol. 2014; 2(2): 152-64.

PubMed Abstract | Publisher Full Text

44. Halperin F, Ding SA, Simonson DC, et al:: Roux-en-Y gastric bypass surgery or lifestyle with intensive medical management in patients with type 2 diabetes: feasibility and 1-year results of a randomized clinical trial. JAMA Surg. 2014: 149(7): 716-26.

PubMed Abstract | Publisher Full Text | Free Full Text

45. F Bethel MA, Patel RA, Merrill P, et al.: Cardiovascular outcomes with glucagon-like peptide-1 receptor agonists in patients with type 2 diabetes: a meta-analysis. Lancet Diabetes Endocrinol. 2018; 6(2): 105-13. PubMed Abstract | Publisher Full Text | F1000 Recommendation 
46. $\mathrm{F}$ Hussein $\mathrm{H}$, Zaccardi $\mathrm{F}$, Khunti $\mathrm{K}$, et al.: Cardiovascular efficacy and safety of sodium-glucose co-transporter-2 inhibitors and glucagon-like peptide-1 receptor agonists: a systematic review and network meta-analysis. Diabet Med. 2019; 36(4): 444-452.

PubMed Abstract | Publisher Full Text | F1000 Recommendation

47. F Bozadjieva N, Heppner KM, Seeley RJ: Targeting FXR and FGF19 to Treat Metabolic Diseases-Lessons Learned From Bariatric Surgery. Diabetes. 2018; 67(9): 1720-8.

PubMed Abstract | Publisher Full Text | F1000 Recommendation

48. F Chikara G, Sharma PK, Dwivedi P, et al: A Narrative Review of Potential Future Antidiabetic Drugs: Should We Expect More? Indian J Clin Biochem. 2018; 33(2): 121-31.

PubMed Abstract | Publisher Full Text | Free Full Text | F1000 Recommendation

49. F Li Z, Zhou Z, Deng F, et al.: Design, synthesis, and biological evaluation of novel pan agonists of FFA1, PPAR $\gamma$ and PPARס. Eur J Med Chem. 2018; 159 267-76.

PubMed Abstract | Publisher Full Text | F1000 Recommendation

50. F Frias JP, Bastyr EJ, Vignati L, et al.: The Sustained Effects of a Dual GIP/
GLP-1 Receptor Agonist, NNC0090-2746, in Patients with Type 2 Diabetes. Cell Metab. 2017; 26(2): 343-352.e2.

PubMed Abstract | Publisher Full Text | F1000 Recommendation

51. F Rendell MS: Sotagliflozin: a combined SGLT1/SGLT2 inhibitor to treat diabetes. Expert Rev Endocrinol Metab. 2018; 13(6): 333-9.

PubMed Abstract | Publisher Full Text | F1000 Recommendation

52. F Neelamkavil SF, Stamford AW, Kowalski T, et al.: Discovery of MK-8282 as a Potent G-Protein-Coupled Receptor 119 Agonist for the Treatment of Type 2 Diabetes. ACS Med Chem Lett. 2018; 9(5): 457-61.

PubMed Abstract | Publisher Full Text | Free Full Text | F1000 Recommendation

53. $F$ Hu YB, Liu XY, Zhan W: Farnesoid $X$ receptor agonist INT-767 attenuates liver steatosis and inflammation in rat model of nonalcoholic steatohepatitis. Drug Des Devel Ther. 2018; 12: 2213-21.

PubMed Abstract | Publisher Full Text | Free Full Text | F1000 Recommendation

54. F Tiessen RG, Kennedy CA, Keller BT, et al:: Safety, tolerability and pharmacodynamics of apical sodium-dependent bile acid transporter inhibition with volixibat in healthy adults and patients with type 2 diabetes mellitus: a randomised placebo-controlled trial. BMC Gastroenterol. 2018; 18(1): 3 .

PubMed Abstract | Publisher Full Text | Free Full Text | F1000 Recommendation 


\section{Open Peer Review}

\section{Current Peer Review Status:}

\section{Editorial Note on the Review Process}

Faculty Reviews are review articles written by the prestigious Members of Faculty Opinions. The articles are commissioned and peer reviewed before publication to ensure that the final, published version is comprehensive and accessible. The reviewers who approved the final version are listed with their names and affiliations.

\section{The reviewers who approved this article are:}

\section{Version 1}

\section{Jorge Calles-Escandon}

Section on Endocrinology, MetroHealth Regional, Case Western Reserve University School of Medicine, Cleveland, Ohio, USA

Competing Interests: No competing interests were disclosed.

\section{Neil Stone}

Department of Medicine, Northwestern University Feinberg School of Medicine, Chicago, Illinois, USA

Competing Interests: No competing interests were disclosed.

\section{Christopher Byrne}

Endocrinology and Metabolism Unit, Southampton General Hospital, University of Southampton, Southampton, SO16 6YD, UK

Competing Interests: No competing interests were disclosed.

The benefits of publishing with F1000Research:

- Your article is published within days, with no editorial bias

- You can publish traditional articles, null/negative results, case reports, data notes and more

- The peer review process is transparent and collaborative

- Your article is indexed in PubMed after passing peer review

- Dedicated customer support at every stage

For pre-submission enquiries, contact research@f1000.com 